\title{
Pure Chromium Sulfate Heptahydrate from Waste Tanning Solutions
}

\author{
Mahmoud A. Rabah \\ Industrial Waste Lab., Chemical and Electrochemical Treatment, \\ Mineral Processing Dept., Central Metallurgical R\&D Institute \\ (CMRDI) P.O.Box 87, Helwan 11421, Cairo, Egypt.
}

\begin{abstract}
7 THS work defines a method for the preparation of pure chromium sulfate heptahydrate from waste tanning solution. The waste resource contains free and soluble fats, calcium hydroxide, iron, magnesium as soluble elements together with chromium ions. The waste solution was filtered to get rid of insoluble materials. This was followed by removal of calcium, iron and magnesium by precipitation as insoluble oxalate salts using 1.3 stoichiometric ratio of oxalic acid in faint acidic medium. Soluble fats were removed by solvent extraction using 1:1 mixture of petroleum ether and isopropanol at $60^{\circ} \mathrm{C}$. The remaining solution contains chromium sulfate together with minor fat impurities. Chromium was selectively precipitated as insoluble hydroxide cake at $\mathrm{pH}$ 8.5. Polyacrylamide $(0.05 \%)$ solution helps fast agglomeration and sedimentation of $\mathrm{Cr}$ $(\mathrm{OH})_{3}$. The hydroxide was washed repeatedly with hot distilled water. The hydroxide cake was partially dehydrated prior to reaction with pure sulfuric acid to prepare pure chromium sulfate solution. Dry chromium sulfate heptahydrate salt was prepared by addition of absolute ethyl alcohol at room temperature whereby the salt is insoluble in alcohol. The influence of some parameters that affect the productivity of the method was studied.
\end{abstract}

Keywords: Chromium sulfate, Tanning waste solutions, Precipitation and Chemical techniques.

Leather tanning industry is based on multi-step processes which include liming, pickling, tanning...., etc and involves the use of various chemicals such as lime, ammonium salts, sulfuric acid, and chromium salts ${ }^{(1)}$. Chromium concentration in terms of total chromium in the exhaust chromium liquor, amounts with a volume of $4 \%$ to $6 \%$ of the total wastewater volume. The discharged waste solution contains chromium ranging from $1.0-1.5 \mathrm{~g} / \mathrm{l}$. The liquor is mixed with other effluent streams from tannery process causing dilution to $100-300 \mathrm{mg} / \mathrm{l}$. In

E-mail : Mahmoud.rabah@ymail.com

Mrabah010@gmail.com

Phone: + 20 25010642, Fax: +20 25010639 
most countries, pollution control authorities do not permit the presence of more than $2 \mathrm{mg} / \mathrm{l}$ of $\mathrm{Cr}(\mathrm{III})$ in treated effluent ${ }^{(2)}$. Composite untreated wastewater, amounting to $20-80 \mathrm{~m}^{3} / \mathrm{t}$ of hide or skin, is turbid, colored, and foul smelling. It consists of acidic and alkaline liquors, with chromium levels of $100-400 \mathrm{mg} / \mathrm{l}$, sulfide levels $200-800 \mathrm{mg} / \mathrm{l}$ while chloride ranges from 200 to $70,000 \mathrm{mg} / \mathrm{l}$ in individual streams. In the combined stream, it amounts 5,600 to $27,000 \mathrm{mg} / \mathrm{l}$ together with high level of fat. Suspended solids are usually half of chloride levels. Tanning wastewater may also contain residues of pesticides used to preserve hides during transport as well as significant level of pathogens. Significant volumes of solid wastes are produced, including trimmings, degraded hide, and hair from the beam house processes. Decaying organic material produces strong odors. Hydrogen sulfide is released during hair removal, and ammonia is released in de-liming ${ }^{(3)}$.

Treatment methods for chromium wastewater may be performed by various processes such as ion exchange ${ }^{(4.5)}$, solvent extraction ${ }^{(6.7)}$ and adsorption ${ }^{(8,9)}$. The precipitation process is the most common because chromium hydroxide is precipitated followed by recovering of chromium by sulfuric acid ${ }^{(10)}$. Awan et al. (11) studied recovery of chromium from waste tannery solution by oxidizing the $\mathrm{Cr}(\mathrm{III})$ to soluble chromate under alkaline conditions. Hydrogen peroxide was potentially a suitable oxidant as it could recover chromate $\left(\mathrm{CrO}_{4}{ }^{2-}\right)$ up to $98 \%$ from synthetic $\mathrm{Cr}^{3+}$ solution and $88 \%$ from effluent. The percentage recoveries by the hypochlorite were lower than those by hydrogen peroxide, i.e. for $\mathrm{NaOCl}$ the recoveries were up to $67 \%$, and $49 \%$ for $\mathrm{Ca}(\mathrm{OCl})_{2}$ from effluent. Removal and recovery of chromium were carried out by precipitation using calcium hydroxide; sodium hydroxide and magnesium oxide were used. The effects of $\mathrm{pH}$, stirring time, settling rate and sludge volume were studied in batch experiments. Results showed that the optimum $\mathrm{pH}$ is 8-9 and the good sludge with high settling rate and lower volume took place by $\mathrm{MgO}$ as a good precipitating agent ${ }^{(12)}$.

Kakakhel et al. ${ }^{(13)}$ studied electrolytic recovery of chromium from tannery waste solution. It was reported that such treatment not only minimizes the environmental water pollution, but results in the formation of useful products employed for recycling purpose in tannery or other related industry to make the process economical. Awan et al. ${ }^{(14)}$ showed that hydrogen peroxide was potentially a suitable oxidant as it could oxidize a suspension of $\mathrm{Cr}(\mathrm{OH})_{3}$ to chromate to $98 \%$ (synthetic solution) and $88 \%$ (wastewater). The percentage recoveries by the hypochlorites were lower than those by hydrogen peroxide. For all three oxidants complete recovery could not be achieved despite different experimental conditions (temperatures and oxidation time). The amount of chromate recovered was determined by spectrophotometry. The results clearly indicated that hydrogen peroxide was the most efficient among the three oxidants. 
Santosa et al. ${ }^{(15)}$ studied adsorption of $\mathrm{Cr}$ (III) from both synthetic and real samples of tannery wastewater treatment's effluent on chitin-humic acid (chitin-HA) hybrid. Rate constant and capacity of adsorption of $\mathrm{Cr}$ (III) from the synthetic sample were investigated and removal of $\mathrm{Cr}$ (III) from the real sample was tested at optimum medium acidity equivalent to $\mathrm{pH} \mathrm{3.5.} \mathrm{Characterization}$ using Fourier transform infra red (FTIR) spectroscopy revealed that both $-\mathrm{COO}^{-1}$ and $\mathrm{N}$-acetyl originated from respectively humic acid (HA) and chitin were involved on the adsorption of Cr(III), and hence the Freundlich's multilayer and multi energy adsorption model was more applicable to treat the adsorption data than the Langmuir's monolayer and mono-energy model. The quantification of adsorption capacity and rate constant using Freundlich isotherm model and first order adsorption reaching equilibrium yielded values of $6.84-10.4 \mathrm{~mol} \mathrm{~g}^{-1}$ (35.57 mg g.1) and $1.70-10.2 \mathrm{~min}^{-1}$, respectively. Removal test for the real wastewater treatment's effluent showed that the maximum amount of $\mathrm{Cr}$ (III) could be removed by $1 \mathrm{~g}$ of chitin-HA hybrid was $2.08-10.4$ mol or equivalent to $10.82 \mathrm{mg}$.

Kilic et al. ${ }^{(16)}$ reported that an oxidative chromium recovery method was environmentally beneficial when tannery sludge contains a chromium concentration of about $100 \mathrm{mg} / \mathrm{l}$. According to the literature, such concentrations are not unusual. The results could serve as the basis for further environmental improvements in chromium recovery and tannery sludge management and should be used in decision-making processes, especially for end-of-pipe treatments .

The objective of this study is to prepare technical pure chromium sulfate heptahydrate salt from tannery waste solution applying a chemical way. Parameters affecting the percent recovery and extent of purity of the product such as temperature, $\mathrm{pH}$, and time and drying conditions were investigated.

\section{Materials and Methods}

a) About $2 \mathrm{~m}^{3}$ of the waste tanning solution was supplied from an industrial tanning workshop in 10 plastic containers having lids (200 1 each). The quantity was collected from stream coming out from tanning drums during discharging.

b) The chemicals and organic solvents were of analytical reagent grade. Polyacrylamide A100 (Cyanamid, France) solution (0.05\% wt) was used as a flocculent.

c) First filtration was carried out using synthetic thin polyester filter cloth 800 mesh, HHH Henan, China. Watman filter paper No. 42 was used for the next filtration processes managed under vacuum.

d) Methods of physical and chemical analysis

1. Density of solution was measured with the help of a density bottle $50 \mathrm{ml}$ capacity. 
2. Metals ions in solution were determined using ICP OES Perkin Elmer Optima 2000 DV, atomic absorption spectro-photometer Unicam SP 1000, and a computerized Philips X-ray diffraction equipment model PW/1710 with Nifilter, $\mathrm{Cu}$ radiation $(\lambda=1.542 \AA)$ at $40 \mathrm{kV}, 30 \mathrm{~mA}$ and scanning speed 0.02 $\%$ sec. was used. The diffraction charts and relative intensities obtained were compared with JCPDS files.

3. Moisture content was determined gravimetrically by drying at $75^{\circ} \mathrm{C}$ for $24 \mathrm{hr}$.

4. Removal of fats was determined gravimetrically. A Soxhlet solvent extraction apparatus was used (Fig. 1). A mixture of 1:1 isopropanol and petroleum ether solvent was used. Extraction was performed for different periods at temperatures up to $60^{\circ} \mathrm{C}$. After each extraction experiment, the waste solution /solvent was transferred to a separating funnel whereby the waste solution was separated from the solvent. Fats extracted were determined gravimetrically by evaporating a certain volume of the separated solvent mixture.

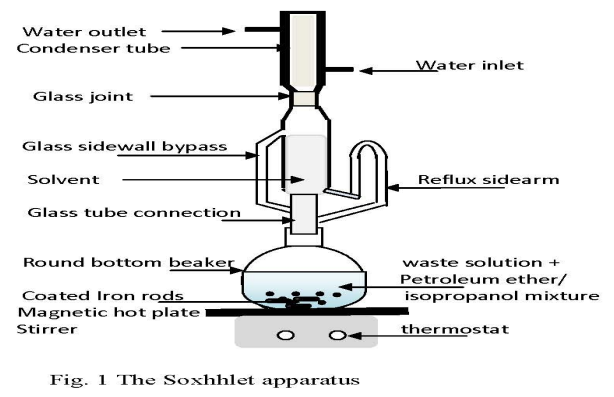

Fig. 1. The Soxhhlet apparatus . 
e) The quality of the produced $\mathrm{CrSO}_{4} \cdot 7 \mathrm{H}_{2} \mathrm{O}$ was determined using ICP OES Perkin Elmer Optima 2000 DV analyzer.

f) Description of the method

1. The raw waste solution was doubly filtered using filter cloth under ambient conditions ( $1^{\text {st }}$ filtrate)

2. The filtrate was heated to boiling for $10 \mathrm{~min}$ and cooled down to room temperature. It was then filtered using Whatman filter paper \# 40 ( $2^{\text {nd }}$ filtrate $)$.

3. Calcium and magnesium ions in the $2^{\text {nd }}$ filtrate were separated as oxalate salts by addition of $0.1 \mathrm{~N}$ oxalic acid in cold conditions. The solution was left stagnant for $24 \mathrm{hr}$ followed by filtration ( $3^{\text {rd }}$ filtrate) using Whatman filter paper Nr. 42.

4. The $3^{\text {rd }}$ filtrate was analyzed with respect to other metals content using ICP OES Perkin Elmer Optima 2000 DV.

5. The obtained solution was turned acidic by addition of $0.05 \mathrm{~N} \mathrm{H}_{2} \mathrm{SO}_{4}$ to a $\mathrm{pH}$ value of 5 and few drops of $\mathrm{H}_{2} \mathrm{O}_{2}$ was added, stirred and then filtered for the $4^{\text {th }}$ filtrate.

6. Chromium in the $4^{\text {th }}$ filtrate was precipitated as hydroxide using $0.5 \mathrm{~N}$ ammonium hydroxide solution. The process was manifested under cold conditions while stirring at $150 \mathrm{rpm}$. About $25 \mathrm{ml}$ of $0.05 \%$ of polyacrylamide flocculent was added to enhance settling of the $\mathrm{Cr}(\mathrm{OH})_{3}$ so formed whereby stirring was stopped. The precipitate was filtered in $5^{\text {th }}$ filtration under vacuum, washed several times with distilled water. It was a gel cake pale green in color with faint smell.

7. The chromium hydroxide gel was left on the filter media for several days for partial dehydration. This was freed from fats by solvent extraction using 1:1 of petroleum ether and isopropanol by volume. Solvent extraction was carried out at temperatures up to $60^{\circ} \mathrm{C}$ and for periods up to $30 \mathrm{hr}$.

8. Fat-free $\mathrm{Cr}(\mathrm{OH})_{3}$ was dissolved in equimolecular quantity of pure sulfuric acid to produce chromium sulfate heptahydrate. This was partially dried under vacuum at $75^{\circ} \mathrm{C}$ and a pure salt was extracted with anhydrous absolute alcohol.

\section{Results}

Analysis shows that the waste solution is alkaline and contains $9.960 \mathrm{~g}$ $\mathrm{Cr}^{3+} / 1$. Table 1 shows the composition of the raw tanning waste solution as received. It is seen that the total TDS amounts to $53.199 \mathrm{~g} / \mathrm{l}$ out of which $20.0 \mathrm{~g} / \mathrm{l}$ sodium chloride.

Figure 2 shows the extent of removal of calcium, iron and magnesium ions from the waste solution as a function of stoichiometric ratio of the oxalic acid reagent. It is seen that for one and the same stoichiometric ratio removal extent decreases in the order calcium, iron and magnesium. Complete removal of these ions takes place with $\geq 1.3$ stoichiometric ratio of oxalic acid. 
TABLE 1. Composition of the tannery waste solution as received .

\begin{tabular}{lcc}
\hline \multicolumn{1}{c}{ Material } & $\begin{array}{c}\text { concentration, } \\
\text { mg/l }\end{array}$ & Remarks \\
\hline Physical appearance & & $\begin{array}{c}\text { Turbid, pale blue-green in } \\
\text { color, with foul smelling }\end{array}$ \\
\hline Free insoluble fats & 42575 & White in color \\
trimmings & 14625 & Pale yellow \\
degraded hide & 8092 & Pale yellow \\
total dissolved solids & 53199 & \\
Calcium & 65.4 & \\
Magnesium & 21.6 & \\
Sodium & 20045 & \\
Chromium & 9960 & \\
Sulfate & 1100 & \\
Chloride & 30892 & \\
Sulfide & 78.6 & \\
pH & 7.8 & \\
\hline
\end{tabular}

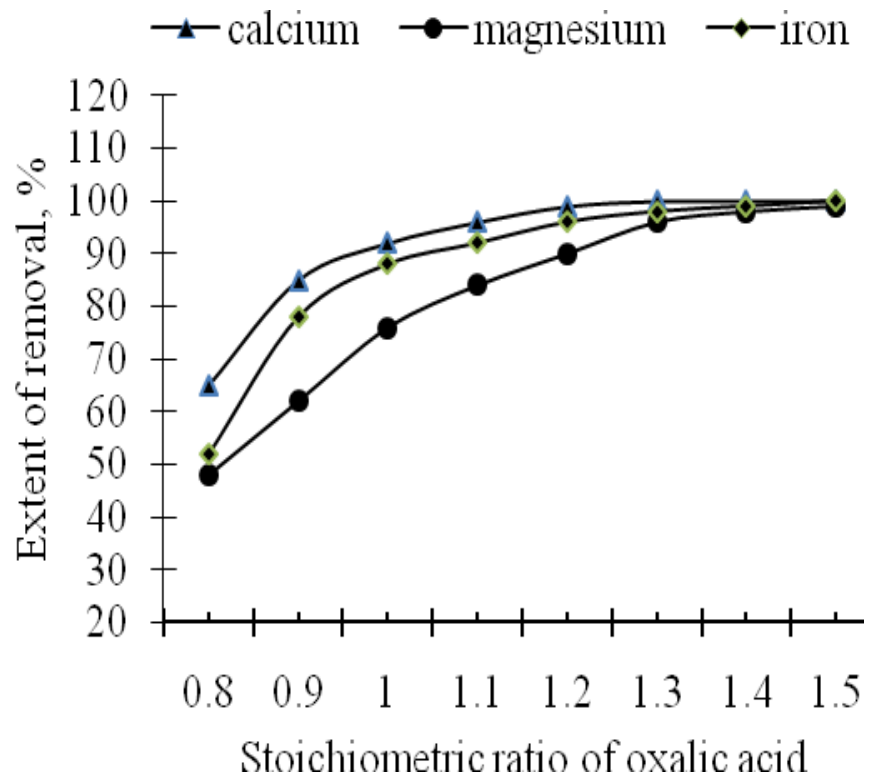

Fig.2. The extent of removal of calcium, magnesium and iron ions from tannery waste solution as a function of stoichiometric ratio of oxalic acid . 
Figure 3 shows the effect of temperature on the extent of removal of these ions using 1.4 stoichiometric ratio of oxalic acid. It can be seen that the extent of removal is inversely proportional with temperature. It can be seen that the extent of removal of calcium, iron and magnesium ions as oxalate is inversely proportional with temperature whereby no removal is seen at $90^{\circ} \mathrm{C}$. Considerable removal takes place at cold conditions

Experiments to degrease the filtrate obtained after removal of calcium, iron and magnesium were carried out by solvent extraction technique using 1:1 mixture of petroleum ether and isopropyl solvents for different times and temperatures. Part of these set of experiments were carried out using partially concentrated waste solution prior to fat removal. Results are graphically represented in Fig. 4 and 5. It can be seen that the extent of removal increases gradually with increase in time. The concentration of the waste solution has only a slight effect

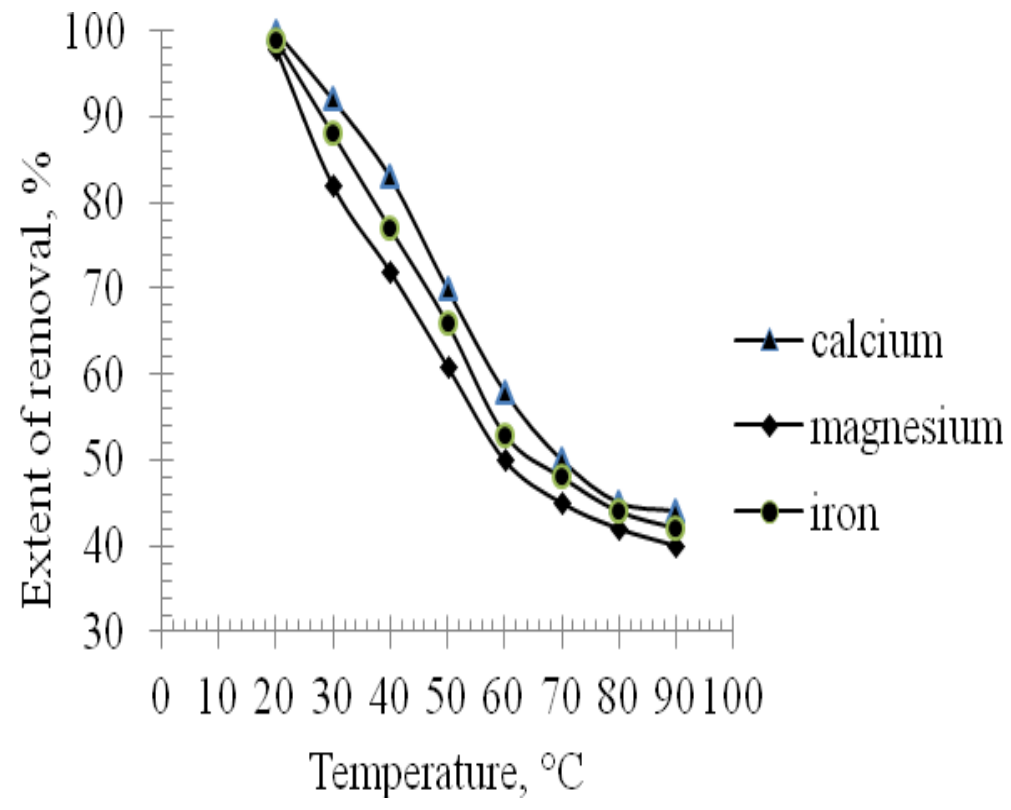

Fig. 3. Effect of temperature on the extent of removal of calcium magnesium and iron ions from the spent tannery waste solution by $0.1 \mathrm{~N}$ oxalic acid. 


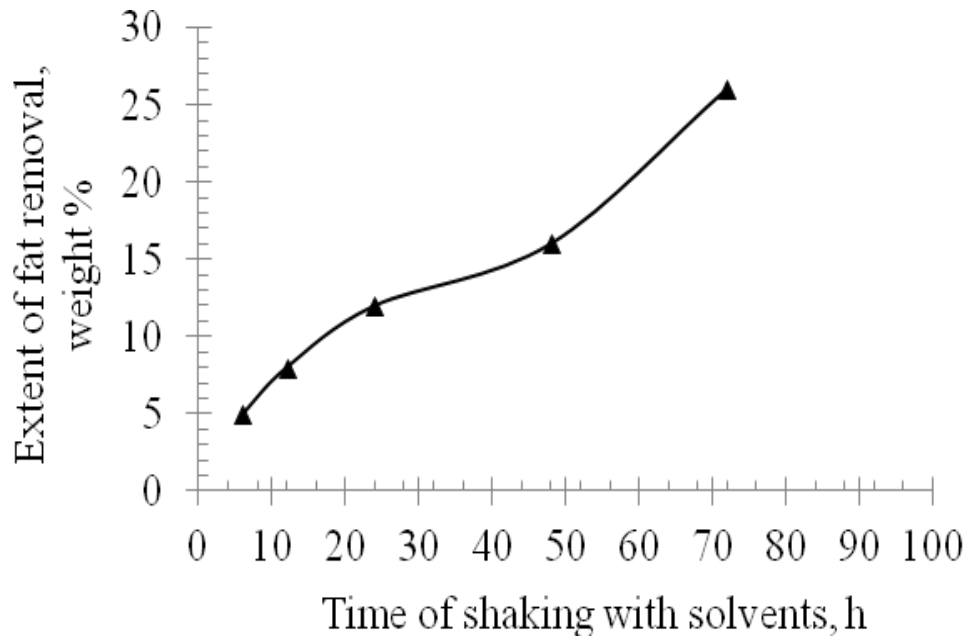

Fig. 4. The extent of fat removal the waste tannery solution $(1 \mathrm{Cr} 3+\mathrm{g} / \mathrm{L})$ as affected by time of shaking with 1:1 petroleum ether and isopropyl solvent at room temperature.

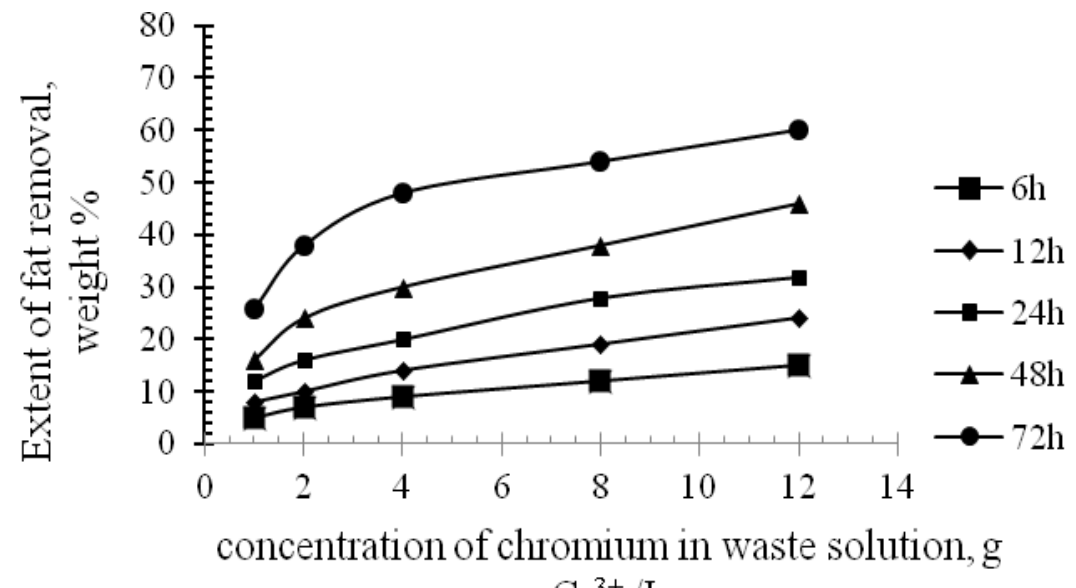

Fig. 5. Effect of $\mathrm{Cr}^{3+}$ ion concentration of the waste tannery solution on the extent of fat removal, using 1:1 petroleum ether and isopropyl solvent mixture, at room temperature. 
Figure 6 shows the extent of fat removal from the chromium solution as a function of temperature of solvent extraction process. It is seen that increasing the temperature favors the extent of fat removal. Maximum temperature was taken at $60^{\circ} \mathrm{C}$ with regard to the boiling point of the solvents used.

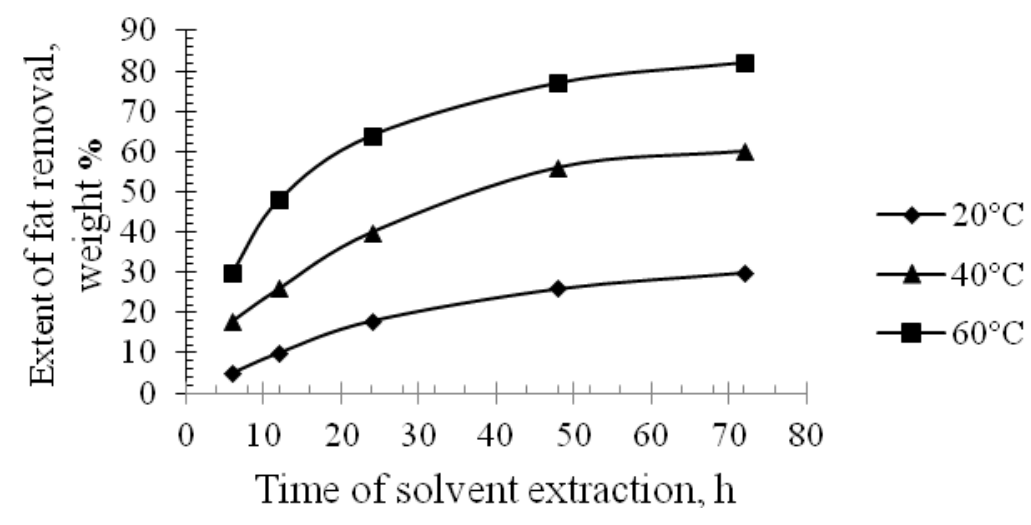

Fig. 6. The extent of fat removal the chromium solution as a function of temperature of solvent extraction process.

The activation energy of the solvent fat removal process was calculated from Arrhenius plot given in Fig.7. The $\Delta \mathrm{H}$ value amounts to 7.78 and $1.6 \mathrm{~kJ} / \mathrm{g}$ for 12 and $48 \mathrm{hr}$, respectively.

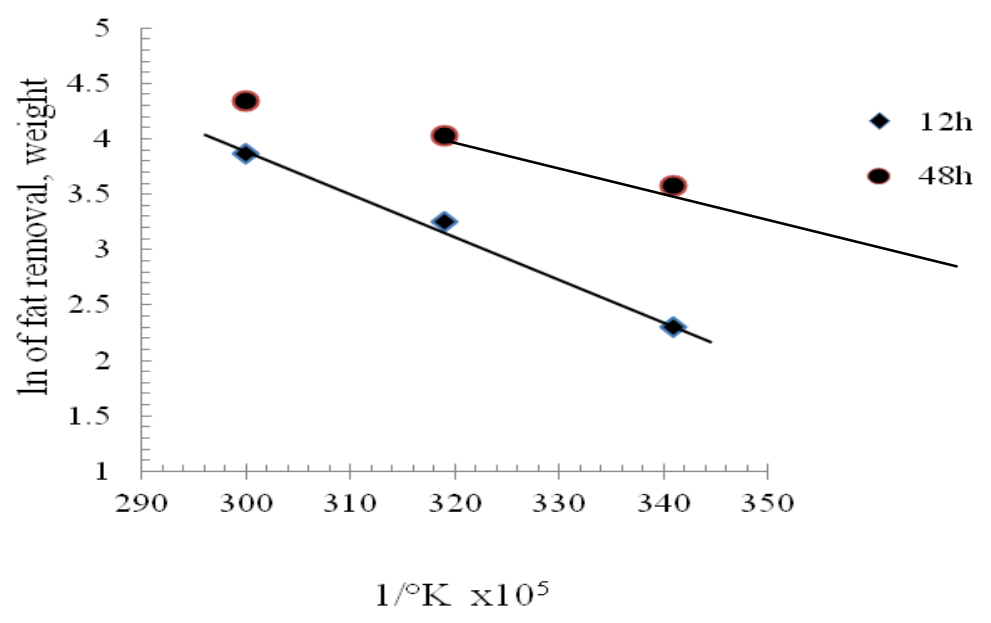

Fig. 7. The Arrhenius plot of the solvent fat removal process . 
Figure 8 shows the settling time of chromium hydroxide gel as a function of addition of $0.5 \%$ (by weight) polyacrylamide polymer solution at different temperatures up to $75^{\circ} \mathrm{C}$ provided that stirring stopped just after the polymer addition. It can be seen that settling time takes place more readily with the addition of $50 \mathrm{ml}$ polymer / 1 waste solution at cold conditions as compared to higher temperatures. The polymer effect becomes less active with rise in temperature. Properties of the gel cake are given in Table 2.

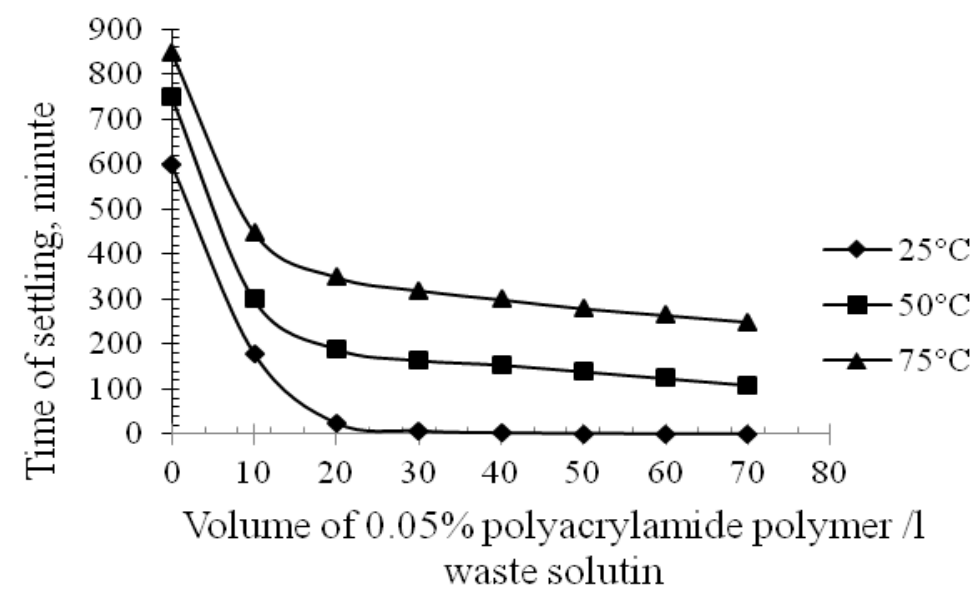

Fig. 8. Effect of addition of $0.05 \%$ polyacrylamide polymer solution ( $\mathrm{ml}$ ) on the settling time of the precipitated chromium hydroxide gel.

TABLE 2 . Properties of the chromium hydroxide gel cake.

\begin{tabular}{lll}
\hline Material & Weight \% & \multicolumn{2}{c}{ Remarks } \\
\hline Water content & 36.4 & The cake is pale bluish \\
$\mathrm{Cr}(\mathrm{OH})_{3}$ & 62.742 & green in color, faint \\
Sodium chloride & 0.852 & smell. \\
Ammonium sulfate-hydrogen & 0.002 & \\
sulfamate $\left(\mathrm{NH}_{4}\right)_{2} \mathrm{SO}_{4}\left(\mathrm{H}_{3} \mathrm{NSO}_{3}\right)$ & & \\
$\mathrm{Ca}^{2+}$ & $16 \mathrm{ppm}$ & \\
$\mathrm{Mg}^{2+}$ & $3 \mathrm{ppm}$ & \\
Soluble fats & 0.001 & \\
\hline
\end{tabular}

Figure 9 shows the fat content in the precipitated chromium hydroxide after solvent extraction at different temperatures and different periods. It is seen that the fat content amounts to 2.5 weight percent in the $\mathrm{Cr}(\mathrm{OH})_{3}$ before solvent extraction. This amount decreases gradually with increasing the extraction time to be $0.02 \%$ after $30 \mathrm{hr}$ at $25^{\circ} \mathrm{C}$ compared to $0.005 \%$ at $75^{\circ} \mathrm{C}$ after the same time. 
Figure 10 shows the water content of the precipitated chromium hydroxide after drying at different temperatures and times. It can be seen that the chromium hydroxide cake holds $99.6 \%$ water just after filtration. Natural drying at room temperature reveals that $\mathrm{Cr}(\mathrm{OH})_{3}$ contains high water content value that slowly decreases with time. After 16 days (384hr) it still conserves 56\% moisture. Drying at $100^{\circ} \mathrm{C}$ is more effective in removing water whereby only $2 \%$ moisture is traced after 4 days.

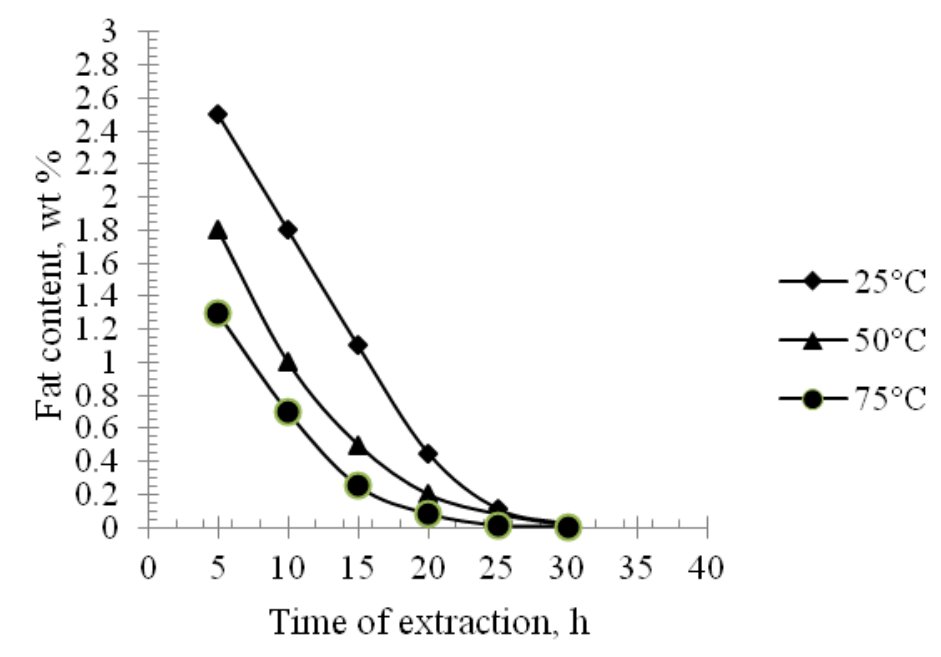

Fig.9. Residual water content of chromium hydroxide gel as affected by time and temperature of drying.

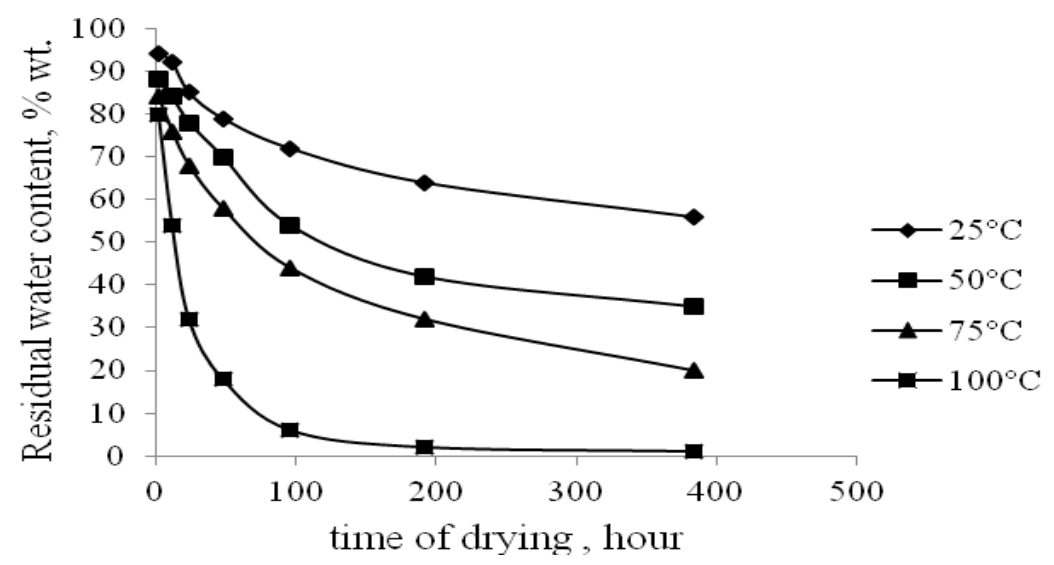

Fig. 10. The fat content in dry $\mathrm{Cr}(\mathrm{OH})_{3}$ as affected by time and temperature of solvent extraction using 1:1 petroleum ether/isopropyl solvent mixture. 


\section{Discussion}

The wastewater used in this study contains free and soluble fats, calcium hydroxide, iron, magnesium, hyper saline effluents and other soluble elements. Wastewater rich in both organic matter and TDS is difficult to treat using conventional biological wastewater treatment processes ${ }^{(17)}$. Among the industries generating hyper saline effluents, tanneries are prominent. In this work, tannery wastewater from soak pit was treated in a lab-scale for the possible recovery of AR grade chromium sulfate heptahydrate salt. The characterization of the soak liquor showed that this effluent is biodegradable, though not easily, and highly variable, depending on the origin and the nature of the hides.

We consider starting the recovery process by getting rid of the large-sized insoluble matters applying comparatively wide pore filter media. The $\mathrm{pH}$ of the solution was adjusted at 5 by addition of few drops of sulfuric acid and $\mathrm{H}_{2} \mathrm{O}_{2}$ to help coagulation of the fats. This was done to alleviate blockage criterion of the filter media as possible as we can. The second filtration was to remove fine insoluble matters and turbidity using narrow pore media. Selection of using synthetic thin polyester filter cloth 800 mesh stands for its chemical ( $\mathrm{pH}$ and $\mathrm{T}$ ) and mechanical stability ( $\Delta \mathrm{P}$ of filtration). After these two filtration steps, free insoluble fats, trimmings and degraded hide were removed.

The filtrate contains soluble fats, sodium chloride, calcium hydroxide and magnesium chloride together with chromium sulfate. It seems reasonable to remove calcium, iron and magnesium content as oxalate salt before precipitating chromium as hydroxide. This finds support from both the solubility product $(\mathrm{Kp})$ and the molar heat of formation values of calcium, iron, magnesium, and chromium oxalate. The Kp value amounts to $1.73 \times 10^{-9}$, $8.57 \times 10^{-5}, 2.1 \times 10^{-7}$ and water soluble for calcium, iron, magnesium, and chromium, respectively ${ }^{(18)}$. The $\Delta \mathrm{H}_{\mathrm{f}}$ value amounts to $-542.8,-825.5$ and -1269 $\mathrm{kJ} / \mathrm{mol}$ for calcium, iron and magnesium ${ }^{(19)}$. It is worth mentioning that $\mathrm{Kp}$ value increases with temperature, e.g. with calcium it amounts to $2.57 \times 10^{-9}$ and $4.36 \times 10-4$ at $25^{\circ} \mathrm{C}$ and $50^{\circ} \mathrm{C}$ as compared to $1.73 \times 10^{-9}$ at $18{ }^{\circ} \mathrm{C}$. However, formation of the oxalate salts of these metals decreases with rise in temperature. For instance, the extent of oxalate formation does not exceed $40 \%$ when the process is carried out at $90^{\circ} \mathrm{C}$. Results given in Fig. 2 and 3 are in a good agreement with this model. Precipitation of oxalate salts is also favored by increasing the stoichiometric ratio (SR) of the oxalic acid reagent. This complies with the law of mass action. In other words, removal of $\mathrm{Ca}, \mathrm{Mg}$, and Fe oxalate takes place more readily with $\geq 1.4 \mathrm{SR}$ and at low temperatures.

Analysis of the chromium solution after removal of calcium, magnesium and iron ions reveals the presence of sodium chloride, chromium sulfate and soluble fats (all are soluble materials). Chromium was recovered by precipitation as hydroxide using $1 \mathrm{M}$ ammonium hydroxide in excess followed by filtration. The filtrate contains halite, soluble fats, ammonium sulfate. The filter cake is 
$\mathrm{Cr}(\mathrm{OH})_{3}$ with ammonium sulfate hydrogen sulfamate $\left(\mathrm{H}_{3} \mathrm{NSO}_{3}\right)\left(\mathrm{NH}_{4}\right)_{2} \mathrm{SO}_{4}$ Table 2 shows the properties and chemical composition of the precipitated $\mathrm{Cr}(\mathrm{OH})_{3}$. Figure 11 shows the XRD pattern of the filter cake. It is seen that $\mathrm{Cr}(\mathrm{OH})_{3}$ and ammonium sulfate hydrogen sulfamate are detected. Formation of the sulfamate compound takes place according to the following sequence:

$\mathrm{Cr} 2\left(\mathrm{SO}_{4}\right)_{3}+6 \mathrm{NH}_{4}(\mathrm{OH}) \longrightarrow 2 \mathrm{Cr}(\mathrm{OH})_{3}+3\left(\mathrm{NH}_{4}\right)_{2} \mathrm{SO}_{4}$

One molecule of ammonium sulfate undergoes decomposition reaction

$\left(\mathrm{NH}_{4}\right)_{2} \mathrm{SO}_{4} \longrightarrow\left(\mathrm{H}_{3} \mathrm{~N}\right) \mathrm{SO}_{3}+\mathrm{H}_{2} \mathrm{O}$

and the $\left(\mathrm{H}_{3} \mathrm{~N}\right) \mathrm{SO}_{3}$ so formed combines with another ammonium sulfate molecule:

$\left(\mathrm{NH}_{4}\right)_{2} \mathrm{SO}_{4}+\left(\mathrm{NH}_{3}\right) \mathrm{SO}_{3} \longrightarrow\left(\mathrm{NH}_{4}\right)_{2} \mathrm{SO}_{4}\left(\mathrm{H}_{3} \mathrm{~N}\right) \mathrm{SO}_{3}$

and the overall reaction: becomes

$\mathrm{Cr}_{2}\left(\mathrm{SO}_{4}\right)_{3}+6\left(\mathrm{NH}_{4}(\mathrm{OH}) \longrightarrow 2 \mathrm{Cr}(\mathrm{OH})_{3}+3\left(\mathrm{NH}_{4}\right)_{2} \mathrm{SO}_{4}+\right.$

$\left(\mathrm{NH}_{4}\right)_{2} \mathrm{SO}_{4}\left(\mathrm{H}_{3} \mathrm{~N}\right) \mathrm{SO}_{3}+\mathrm{H}_{2} \mathrm{O}$

Ammonium sulfate hydrogen sulfamate is a weak compound and decomposes by heating according to
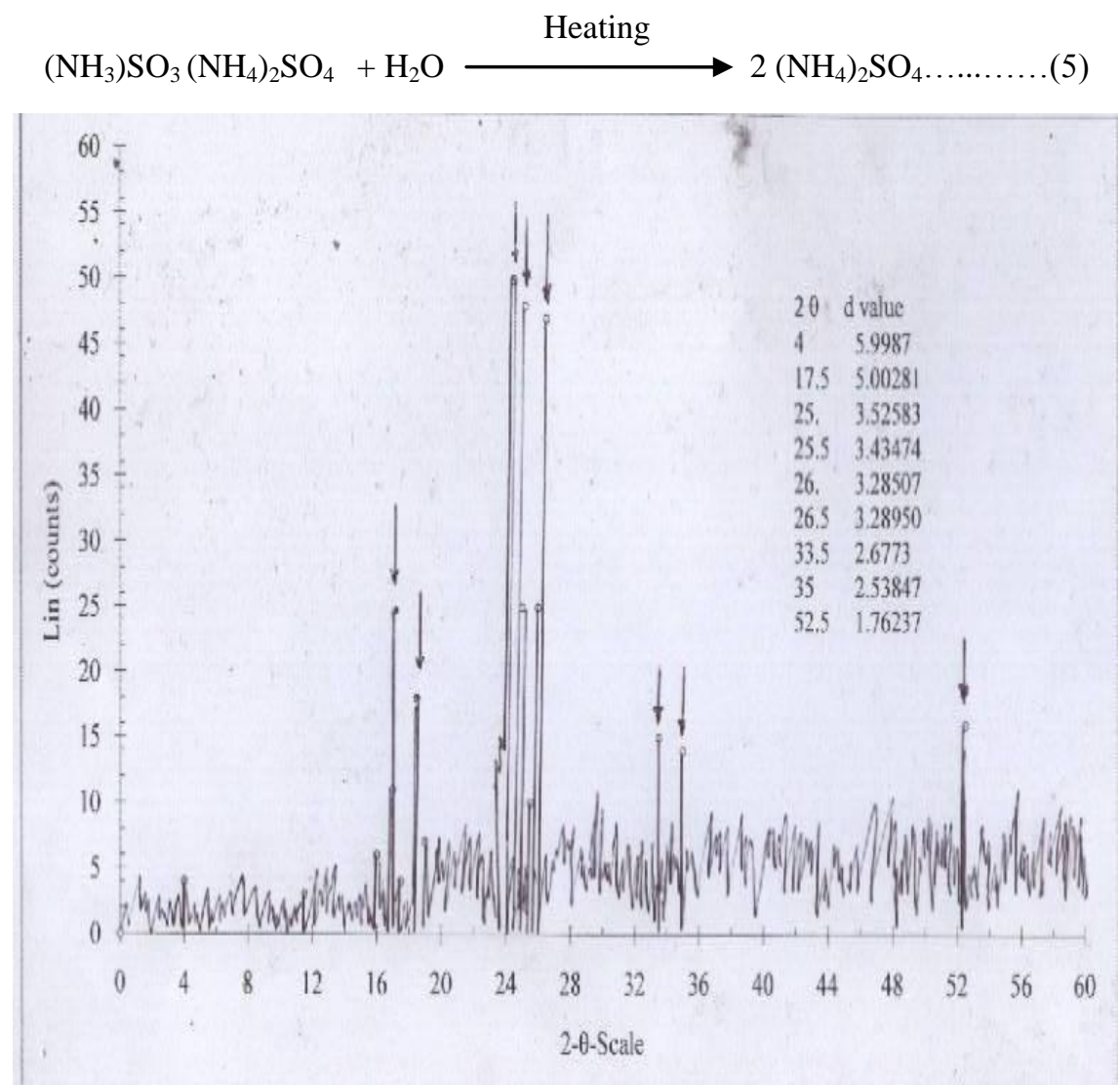

Fig.11. The XRD pattern of ammonium sulfate hydrogen sulfamate . 
It becomes critical to avoid the use of ammonia reagent in excess to precipitate $\mathrm{Cr}(\mathrm{OH})_{3}$. Experimental finding confirms that 1.1 stoichiometric ratio of 1.M ammonia solution is sufficient to precipitate $\mathrm{Cr}(\mathrm{OH})_{3}$ free of ammonium sulfate hydrogen sulfamate complex compound.

Although the filter cake was washed 3 times with water, yet some fats were traced. Extraction of such traces was carried out by solvent extraction technique. Results reveal that soluble fats are adsorbed by the chromium hydroxide molecules due to difference in molecular polarity. As lipids are relatively non-polar molecules, they can be pulled out using relatively nonpolar solvents. Problems arise however, in cases where lipids are bound in animal or plant cell membranes. Animal and plant cell membranes are made up of molecules that have both polar and non polar regions such as triglycerides (molecule with polar glyceride heads and non-polar fatty acid tails) and phospholipids (similar to triglycerides, but a phosphate group replaces the fatty acid tail). These molecules end up grouping together with their polar heads sticking outwards and non-polar tails inwards making it difficult for non-polar solvents to interact with the non-polar tails and extract them. As these molecules are part non-polar and polar we need a solvent that presents some of these same characteristics. This is why we used a mixture of two solvents; non polar (petroleum ether) and polar (isopropanol). The mixture is enough to interact with the polar region and help "pull apart" the polar fats of the cell membrane while also being non-polar enough to help in extracting non-polar fats. This is judged from the fact that complete extraction of fats takes place after $30 \mathrm{hr}$. It is also found that fats extraction takes place more readily with rise in temperature. Increasing the extraction temperature increases the dissolving power of the organic solvents. High temperature provides the system with thermal energy enough to enhance interaction of both the solvent and the fats ${ }^{(19)}$.

Pure chromium hydroxide reacts with sulfuric acid to yield chromium sulfate heptahydrate according to:

$2 \mathrm{Cr}(\mathrm{OH})_{3}+3 \mathrm{H}_{2} \mathrm{SO}_{4}+\mathrm{H}_{2} \mathrm{O} \longrightarrow \mathrm{Cr}_{2}\left(\mathrm{SO}_{4}\right)_{3} \cdot 7 \mathrm{H}_{2} \mathrm{O}$

The product was carefully concentrated by partial drying at $75^{\circ} \mathrm{C}$ under vacuum. Dry salt of chromium sulfate heptahydrate was obtained from the concentrated solution by addition of absolute ethyl alcohol whereby the salt is insoluble. The alcohol was recycled by distillation. The obtained chromium sulfate is crystalline in form, blue in color and hygroscopic. ICP OES investigation confirms the salt quality is pure. Table 3 shows the physicchemical properties of the obtained chromium sulfate salt whereby Fig. 12 shows the XRD pattern of the salt so obtained. 
TABLE 3. Properties of the obtained chromium salt .

\begin{tabular}{cc}
\hline Material & Wt \\
\hline Chemical formula & $\mathrm{Cr}_{2}\left(\mathrm{SO}_{4}\right)_{3} .7 \mathrm{H}_{2} \mathrm{O}$ \\
color & Blue crystals \\
Assay $\mathrm{Cr}_{2}\left(\mathrm{SO}_{4}\right)_{3}, \%$ & 99.995 \\
$\mathrm{Fat}, \%$ & 0.002 \\
$\mathrm{Ca}^{2+}, \%$ & 0.0001 \\
$\mathrm{Mg}^{2+}, \%$ & 0.0004 \\
$\mathrm{Na}^{+}, \%$ & nil \\
$\mathrm{Fe}^{2+}, \%$ & nil \\
Density, $\mathrm{g} / \mathrm{cm}^{3}$ & 2.438 \\
Solubility in & \\
$100 \mathrm{~g}$ water, $25^{\circ} \mathrm{C}$ & 12.35 \\
\hline
\end{tabular}

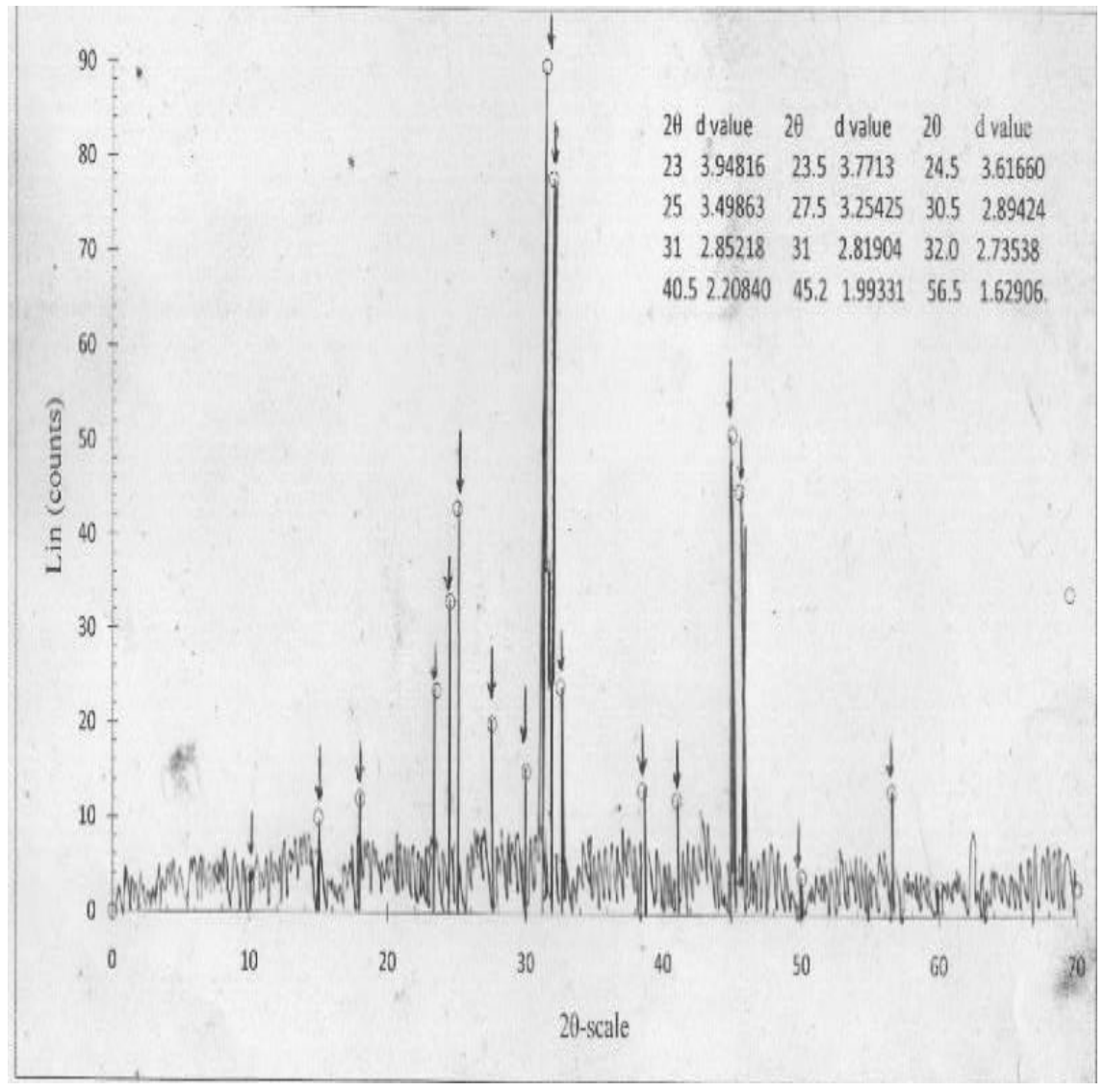

Fig.12. The XRD of chromium sulfate (end product) .

Egypt. J. Chem. 55, No. 2 (2012) 
Techno-economic evaluation of the cost of the product

Preliminary techno-economic study had been carried out to evaluate the cost price of the product. Analysis was based on the following assumptions:

1. The tanning industry is continuous at the present rate for at least 20 years.

2. The chromium content in the waste solution is not liable to major changes.

3. The waste solution is priceless.

4. The market price of the chemicals and charges of energy is annually increasing at rate of 5-6\%

5. The labor cost is nearly constant

6. Overhead charges of the equipment and facilities amounts to $15 \%$.

The net output result revealed that the market price of the end product is highly competitive to the price of the same material having the same quality obtained from raw resources.

\section{Conclusion}

Pure chromium sulfate was recovered from waste tannery solution. The waste resource contains free insoluble fats together with other soluble metal ions. The route applied to recover chromium sulfate involves removal of insoluble matters by filtration. Soluble salts other than chromium in the filtrate are separated by precipitation as oxalate. Soluble fats are extracted with the help of a mixture of a non polar (petroleum ether) and a polar solvent (isopropanol) solvents. Chromium was then separated as hydroxide followed by reaction with pure sulfuric acid to yield pure chromium sulfate solution. This was partially concentrated by drying. The dry salt of chromium sulfate heptahydrate was obtained by addition of ethyl alcohol to the concentrated solution whereby the salt is insoluble in the alcohol. The alcohol was recovered by distillation. Techno-economic study of the cost of the process shows that it is very competitive to the market price of the chromium sulfate having the same quality.

\section{References}

1. Fadali, O.A., Magdy, Y.H., Daifullah, A.A.M., Ebraheim, E.E. and Nassar, M.M., Removal of chromium from tannery effluents by adsorption. J. Environ. Sci. Health, Part A, 39 (2), 465 (2004).

2. Yalcin, S., Apak, R., Hizal, J. and Afsar, H., Spectrophotometric analysis for quality control in treatment of chromium recovery. Sep. Sci. Technol. 36 (10), 2181 (2001).

3. WORLD BANK GROUP Handbook, Pollution Prevention and Abatement Tanning and Leather Finishing Draft Technical Department, Washington, D.C Effective July (1998).

4. Kamel, M., Mijangos, F. and Elizalde, M.P., Chromium extraction from tannery wastewater. Solvent Extr. Ion Exch. 20 (4, 5), 575 (2002).

Egypt. J. Chem. 55, No. 2 (2012) 
5. Bakircioglue, Y., Bakircioglue, D., Akman, S. and Instrum, Monitoring chromium content in tannery wastewater . Sci. Technol. 21(3), 467 (2003).

6. Narin, M., Soylak, K., Kayakirilmaz, L.E. and Dogan, M., Speciation of Cr(III) and $\mathrm{Cr}(\mathrm{IV})$ in tannery wastewater and sediment samples on Ambersorb 563 resin. Anal. Lett. 35 (8), 1437 (2002) .

7. Milich, P., Möller, F., Píriz, J., Vivó, G. and Tancredi, N., The influence of preparation methods and surface properties of activated carbons on $\mathrm{Cr}(\mathrm{III})$ adsorption from aqueous solutions. Sep. Sci Technol. 37 (6), 1453 (2002) .

8. Hasan, S., Krishnaiah, A., Ghosh, T.K., Viswanath, D.S., Boddu, V.M. and Smith, E.D., Adsorption of Cr(VI) on chitosan-coated perlite, Sep. Sci. Technol. 38 (15), 3775 (2003).

9. Dahbi, S., Azzi, M., Guardia, M. and Fresenius J., Removal of hexavalent chromium from wastewaters by bone charcoal. Anal. Chem. 363, 404 (1999).

10. Banerjee, S.S., Joshi, M.V. and Jayaram, R.V., Removal of $\mathrm{Cr}(\mathrm{VI})$ and $\mathrm{Hg}(\mathrm{II})$ from aqueous solutions using fly ash and impregnated fly ash. Sep. Sci. Technol. 39(7), 1611. (2004) .

11. Awan, M. A. Baig, I . A. Iqbal, J., Aslam, M.R. and Ijaz, J. N., Recovery of chromium (III) from tannery wastewater. J. Appl. Sci. \& Env. Manag. 7(2) Dec, pp. 5-8. (2003)

12. Esmaeili, A., Mesdaghi, A. and Vazirinejad, R., Chromium (III) removal and recovery from tannery wastewater by precipitation process. Am. J. Appl. Sci. 2 (10), 1471-1473 (2005).

13. Sirajuddin, L.K., Lutfullah, G., Bhanger, M.I. and Abdul Niaz, A.S., Electrolytic recovery of chromium salts from tannery wastewater. J. Hazard. Mater. 148 (3), 560-565 (2007).

14. Awan, M.A., Baig, I.A., Iqbal, J., Aslam, M.R. and Ijaz, N., Recovery of chromate from tannery wastewater. Electronic Journal of Environmental, Agriculture and Food Chemistry, EJEAF Che, 2 (5), 543-48 (2003).

15. Santosa, S.J., Siswanta, D., Sudiono, S. and Utarianingrum, R., Chitin-humic acid hybrid as adsorbent for $\mathrm{Cr}(\mathrm{III})$ in effluent of tannery wastewater treatment. Appl. Surf. Sci. 254, 7846-7850 (2008) .

16. Kilic, E., Puig, R., Baquero, G., Font, J., Colak, S. and D. Guiler., Environmental optimization of chromium recovery from tannery sludge using a life cycle assessment approach. J. Hazard. Mater, 192 (1), 393-401 (2011).

17. Lefebvre, O., Vasudevan, N., Torrijos, M., Thanasekaran, K. K. and Moletta, R. Halophilic biological treatment of tannery soaks liquor in a sequencing batch reactor. Water Res. 39(8), 1471-1480 (2005). 
18. Weast, R.C. and Astle, M.J., CRC Hand book of Chemistry and Physics. $86^{\text {th }}$ ed. B220, CRC Press Inc. Boca Raton, Florida, USA (1986).

19. Matos, L., Nzikou, J.M., Matouba, E., Pandzou-Yembe, V.N., Mapepoulou, T.G., Linder, M. and Desobry, S., Studies of Irvingia gabonensis seed kernels: Oil technological applications. Park J. Nutr. 8, 151-157. (2009).

$$
\begin{aligned}
& \text { تحضير كبريتات الكروم عالية النقاوة من محلول الصرف من مدابغ } \\
& \text { الجلود } \\
& \text { محمود رباح } \\
& \text { معمل معالجة المخلفات ـ قعم الخامات ـ مركز بحوث وتطوير الفلزات ـ حلوان - }
\end{aligned}
$$

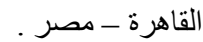

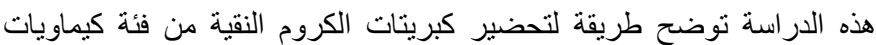

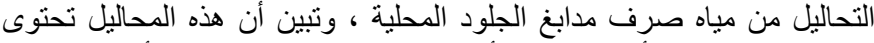

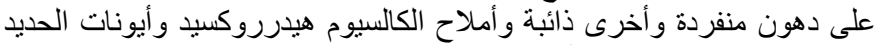

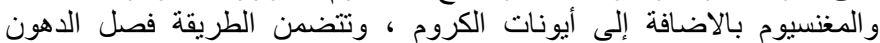

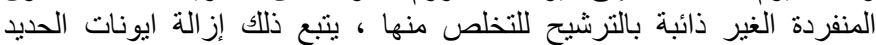

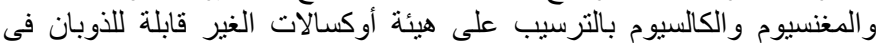

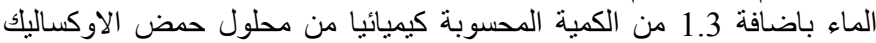

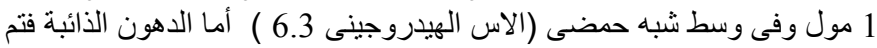

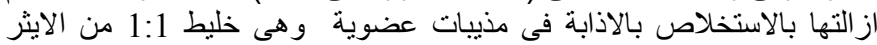

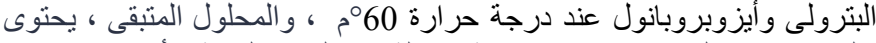

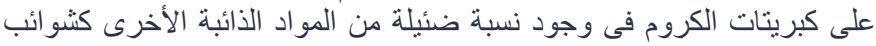

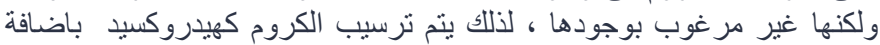

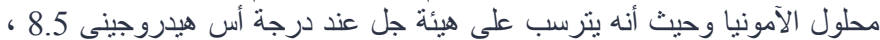
وللالك يتم إضافة كمية قليلة من محلول 0.05 \% من كن البولى أكريلاميايد كمادة

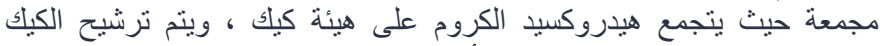

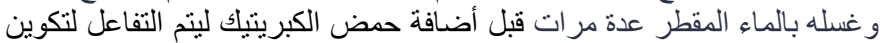

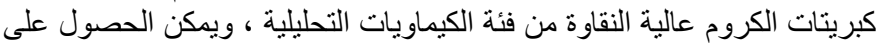

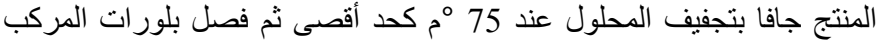

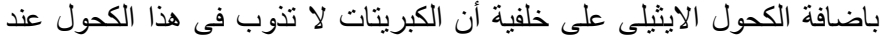

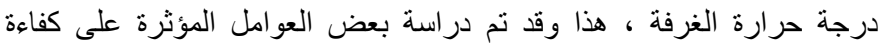

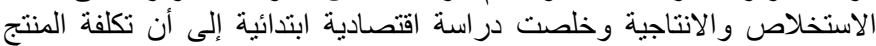
منخفضة بالنسبة لسعر ذات المركب و المحضر من الخامات الاولية. 